\title{
Mangrove Health Assessment and Genetic Diversity of Associated Sesarmid Crab Parasesarma Persicum in Nayband National Park, Iran
}

Maryam Dehghani

Persian Gulf University

Ahmad Shadi ( $\nabla$ shadi@pgu.ac.ir)

Persian Gulf University https://orcid.org/0000-0002-4896-8817

Yasaman Gandomi

Khorramshahr Marine Science and Technology University

Ahmad Ghasemi

Persian Gulf University

\section{Research Article}

Keywords: Genetic diversity, Mangrove Quality Index, AFLP method, Avicinna marina

Posted Date: June 7th, 2021

DOl: https://doi.org/10.21203/rs.3.rs-516864/v1

License: (a) (i) This work is licensed under a Creative Commons Attribution 4.0 International License. Read Full License 


\section{Abstract}

Mangrove forests as one of the most important coastal ecosystems provide important ecological and economic performance to the world, have been threatened by developmental human activities and subsequent land use changes. The present study aims to assess mangrove ecosystem health in Nayband Marine National Park, Iran using Mangrove Quality Index (MQI), in addition to analyse the effect of mangrove habitat quality on the genetic diversity of Parasesarma persicum the associated mangrove crab by amplified fragment length polymorphism (AFLP). Four stations were studied for mangrove quality index analysis as well as genetic analysis. The results of MQI survey based on hydrology, water, soil, biota criteria indicated moderate to low habitat quality of mangroves in the study area. Station 4 in the southern Nayband gulf showed highest impact by human activities and MQI of 0.7 , indicating serious habitat alteration in this area. Station 2 in the northern part of Nayband gulf showed a moderate mangrove quality $(\mathrm{MQI}=0.5)$. Based on the results of the AFLP genetic assessment, the estimated heterozygosity $(\mathrm{He})$ of crabs was between 0.29 to 0.32 with a mean of 0.30 . The highest genetic diversity was found at station 2, however, no complete population differentiation was observed between 4 stations. The analysis revealed a significant correlation between mangrove habitat alteration and heterozygosity reduction $(P<0.05)$. Based on the results of the present study, mangrove habitat destruction due to anthropogenic activities may directly reduce the genetic diversity of associated species of this ecosystem.

\section{Introduction}

Mangrove forests are halophytic vegetations located along the coastlines of tropical and subtropical areas between latitudes of $24^{\circ} \mathrm{N}-38^{\circ} \mathrm{S}$. These intricate network of highly productive habitats are located on the margins of estuaries. Salt tolerant mangrove trees consist of 63 species and 18 families and 24 genera including Rhizophora, Aegialitis, Ceriops, Sonneratia, Avicenni and Xylocarpus(Erfani et al. 2009).

This rich and highly productive ecosystem covering about $136,714 \mathrm{~km}^{2}$ of the coastal areas in 121 countries(Tang et al. 2018). Mangrove forests are among the most valuable coastal habitats(Spalding et al. 2010). The characteristic of mangrove trees is their high resistance to salinity and the respiratory air roots(Erfani et al. 2009). They have massive roots that are very effective in wasting energy and protecting the coast from the erosion due to long-wave storms and tsunamis(Dahdouh-Guebas et al. 2005). Mangrove trees absorb carbon dioxide from the atmosphere and conserve carbon over time in the surrounding soil, thereby significantly reducing the amount of carbon released into the atmosphere. These ecosystems serve as a sanctuary and shelter for many terrestrial and marine species(Su et al. 2010). Mangrove forests are sensitive to pollutants and other stresses caused by human activities. Hence, more attention to conservation of biological diversity of mangrove forests raised during the last decades. The human source ecological disturbances in aquatic ecosystems are major environmental problems at the regional and global level. Human activities resulted in alterations such as habitat loss and biodiversity reduction. Therefore, integrated management approaches are necessary to maintain the performance and integrity of the marine ecosystems. 
In order to evaluate the health of an ecosystem, it is generally necessary to examine the dynamics of all system components under stress and non-stress conditions. Due to the necessity of mangrove management and monitoring, various indicators for evaluation along with detailed health indices have been introduced (SPI, NDVI, SSI). These methods enabled researchers to monitor and evaluate the ecosystem health and the changes over long period of time, and very large areas. This index is also used for perennial monitoring(Abbaszadeh 2016). Many other indicators are also used to evaluate the ecological status of wetlands such as RAI, WFI, LAI, HGM, SQI. Mangrove Quality Index(MQI) is one of the new and specialized mangrove indicators which is a fast, low cost and easy to use tool for tracking changes in mangrove quality. The index provides the best comparison of data between monitoring stations at the national, regional and global levels and can involve further analysis of the mangrove quality on a wider geographic scale(Faridah-Hanum et al. 2019).

The MQI is an indicator developed specifically for mangrove forests and covers the shortcomings of other methods. The Mangrove Quality Index is a rapid assessment method identified by Sutula (Sutula et al. 2006). This index is also used for mangrove quality monitoring and decision making by managers.

In recent decades, anthropogenic activities caused habitat alteration and resulted in genetic alterations in natural populations. Thus monitoring of genetic diversity can provide insights into the consequences of environmental change(Bagley 2002; Fratini et al. 2008). The accuracy and sensitivity of genetic diversity monitoring has increased with the advancement of molecular marker technologies. Genetic conservation is a key to the long-term survival of most species(Ling et al. 2009). The main goal of genetic management is to ensure that the genetic diversity is sufficient for short-term adaptation as well as longterm stability. Mangrove crab is one of the keystone species in mangrove forest ecosystem. The abundance and activity of crabs is one of the most indicator features in mangrove ecological populations.

The holes created by crabs increases the soil-to-air ratio and lead to aeration and oxidation of mangrove soils. This oxidation has been reported to be important for the growth of mangrove plants. These organisms play role in the structuring and function of mangroves. In addition, they are detritus feeders and are important in dynamics of nutrients and alter sediment properties by their drilling activities. As the result, crab population changes can affect the food cycle and soil oxidation. The decrease in crab population and its associated density may result in a decrease in the nutrient and aeration cycle of the soil and a decrease in crop production(Lindquist et al. 2009). On the other hand, the quality and ecological health of mangrove ecosystem as a nursery and habitat for these crab species, influence the biological characteristics of associated fauna.

Different crab species have been identified in Neyband Bay mangrove forests include Cyphocrcinus capreoluss, Thalmita savighyi, Parasesarma persicum(Naderloo 2017). Parasesarma persicum from family Sesarmidae is the most common and dominant crab species in the mangroves of Nayband National Park(Naderloo 2017). Genetic diversity is an essential part of biodiversity and also plays an 
important role in the sustainability of ecosystems, species and populations. Therefore obtaining basic genetic data is essential for species and ecosystem conservation(Takezaki and Nei 1996).

Genetic diversity through genetic drift Selection of mutations and gene flow responds to changes and environmental degradation(Bagley 2002). Evaluation might be performed using a variety of markers to assess genetic diversity on a larger scale(Tanksley and Orton 2012). Molecular markers are widely used in recent years for diversity assessment of different species in habitat and species level as well as population studies.

In the present study, the amplification fragment length difference (AFLP), which represents the PCR-based DNA marker, was used to evaluate the genetic diversity of sesarmid crab P.persicum which is the most common mangrove associated species in the Nayband national park. The AFLP marker is a generic method which does not require former genetic information of the species(Vos et al. 1995). The present study aims to rapid evaluation of human activities effects on Nayband National Park mangroves using Mangrove Quality Index and its probable consequence effect on genetic variation of crab species Parasesarma persicum.

\section{Material And Methods}

\subsection{The study area}

Bushehr province is located in southern Iran, north Persian Gulf with an area of about $27653 \mathrm{~km}^{2}$. Nayband Marine National Park $\left(26^{\circ} 35^{\prime}\right.$ to $28^{\circ} 88^{\prime} \mathrm{N}, 51^{\circ} 20^{\prime}$ to $55^{\circ} 22^{\prime} \mathrm{E}$ ) been listed as marine protected area since 1996. The park now includes a total area of 484400 hectares, $35.8 \%$ of which is intertidal zone, and $64.2 \%$ the marine areas up to $20 \mathrm{~m}$ depth from the coastline.

Four sampling stations were selected along the coastal line of the study area based on the overall degree of human impact on the forest ecosystem (fig.1). The locations of transects were determined by primary field observation of the study area. Three replicates were randomly generated at each station to study the ecological health of mangrove forest and the genetic diversity of Parasesarma persicum the common associated crab.

\subsection{Field examination and sampling}

Field examination and sampling was performed during March 2020. Descriptive information was recorded at field observation including mangrove vegetation, the overall human impact, land use, and attributes of mangrove quality index (hydrology, water, soil, biota) based on the method provided by Wilson et al.(Wilson 2009)

In the present study, four stations were selected in the mangrove habitats of Nayband Bay, based on the growth of mangrove trees in the estuaries, surrounding land use and overall anthropogenic impacts. Three replicates were sampled at each station. 
Primary information was obtained by rapid assessment of the study area. Rapid and low technology based primary observation of the area is a good approach to determine the current condition of the mangroves, and to obtain basic information for future precise examinations(Ellison and Zouh 2012). At the coastline, an observation point was selected along the stations, and information on the type of mangrove species and conditions up to a radius of 15 meters at each point was recorded. Anthropogenic impacts recorded based on the MQI index on a scale of 1-5, with scale 1 indicating no human modification and scale 5 indicating high anthropogenic destruction(Smith and Wakeley 2001; Sutula et al. 2006).

To determine the mangrove recruitment ability, the presence of mangrove propagules in each area is scored on a scale of 1-5. Score 1 is when if all mangroves produce propagules, and score 5 when no propagules are observed. Reserve recovery is an indicator of mangrove health and adaptive capacity(Smith and Wakeley 2001; Sutula et al. 2006).

The Mangrove Quality Index (MQI) is considered as an appropriate tool for the management of coastal habitats as a rapid cost effective method in contrast to other assessment methods. Criteria have been set for inclusion and measurement in the mangrove quality index based on existing surveys and evaluation methods(Kathiresan and Bingham 2001; Wilson 2009; Ibrahim et al. 2016). These criteria (Table1) also assess the status of ecosystems in terms of hydrological flow, water quality, soil and biota.

\section{Table 1. Ecological health status criteria}

\begin{tabular}{|lll|}
\hline Indicators & Description & Attribute \\
$\begin{array}{l}\text { To be determined later (to include } \\
\text { factors such as roads, ditching, canals, } \\
\text { boat basins etc) }\end{array}$ & $\begin{array}{l}\text { Measures the amount of } \\
\text { hydrologic changes on site }\end{array}$ & \\
\hline Turbidity, chlorophyll a & Measures physical & Water \\
& properties of water in the & \\
& mangroves & \\
organic content, sediment & Characterizes the soil on site & Soil \\
composition (size/type) & & Biota \\
\hline $\begin{array}{l}\text { Composition and abundance of } \\
\text { mangrove species, neighboring land } \\
\text { use, crab holes }\end{array}$ & Determines species & \\
\hline
\end{tabular}

Therefore, the following sampling was performed for each station:

\subsubsection{Field Sampling}


Water-Water factors was scored using Mangrove Quality Index. $\mathrm{pH}$, temperature, salinity and dissolved oxygen were measured using portable moltiparameter meter. Chlorophyll and turbidity were measured using Algatorch (bbe moldanke,Germany).

Biota- A $0.5 \mathrm{~m}$ quadrant were used to count the holes created by crabs as a measure for crab abundance. Vegetation density was measured by point centered quarter model (pcqm)(Mueller-Dombois and Ellenberg 1974), Basal Area as a physical index was used to identify and compare the health status of trees(Smith and Wakeley 2001; Sutula et al. 2006). This index reflects the mangrove health, whereas the number 1 indicates the pristine and natural condition and the number 5 indicates the lowest quality of mangroves and highest human impact.

Soil - One of the essential properties for plant community health is the composition of sediments. There is a positive relationship between the condition of sediments and its density (Whigham 1999). 400 to 500 $\mathrm{g}$ of sediment was collected using a shovel and transferred to the laboratory for analysis of organic matter and sediment grading. The organic content of the sediments was determined. loss on ignition method (Nelson and Sommers 1996) using an electric furnace model FM4P. The composition of sediments was analyzed by sieve analysis outlined by Mcintyre and Eleftheriou(2005).

\subsection{Additional observations:}

Hydrological description as well as tides and weather condition in addition to surrounding land use and human activities around the stations were described and recorded.

Overall Mangrove Quality Index - To calculate the Mangrove Quality Index, obtained by dividing the calculated score(1-5) to the accumulative possible scores(20) which results a score between 0-1, where the 1 is assigned to the most pristine condition where no human impact is observed, and 0 assigned to mangrove ecosystems which highly affected by human activities.

\subsection{Genetic analysis of sesarmid crab Paracisarma persicum}

\subsubsection{AFLP marker analysis}

For genetic examinations, 10 specimens of sesarmid crab Paracisarma persicum were collected from each station. The specimens were placed in clear bottles containing $95 \%$ ethanol and transferred to the laboratory. Extraction of DNA from tissue was performed by CTAB method(Mirimin and Roodt-Wilding 2015). For quantitative and qualitative evaluation of DNA, $1 \%$ agarose gel and spectrophotometry were used. The AFLP steps were performed according to the VOS et al(Vos et al. 1995)method with slight modifications based on the optimized method in the Persian Gulf University Research Institute as follows. Digestion step: digestion of $300 \mathrm{ng}$ of total DNA by $5 \mathrm{u}$ of the Msel and EcoRI cleavage enzymes in Restriction Enzyme Buffer at $37^{\circ} \mathrm{C}$ for $2 \mathrm{~h}$ and $30 \mathrm{~min}$ and then at $65^{\circ} \mathrm{C}$ for $2 \mathrm{~h}$ and $30 \mathrm{~min}$. Then, in the ligation phase of the insertion of the Msel and EcoRI adapters with the desired sequence and at the concentration of $50 \mathrm{~mm}$ with the T4DNA ligase and the insertion buffer for $10 \mathrm{~h}$ at $22^{\circ} \mathrm{C}$ at the cut ends. The reaction products were then diluted 4 times and the resulting product was plated on agarose gel to 
confirm the reaction. Components were amplified during two stages of pre-selection and selective amplification. Primary PCR is pre-selected. This reaction was performed by combining the primers E01 = 5'-GACTGCGTACCAATTCA- 'and M02 = 5'-GATGAGTCCTGAGTAAC-3' primers, which are complementary to the adapters and have an additional nucleotide at the 3 'end. In the second step of amplification, $5 \mu l$ of the products from the pre-selective amplification of the selective PCR reaction were performed with the 6 primers combinations listed in the(Table2). The resulting products were electrophoresed on $6 \%$ polyacrylamide gel followed by silver nitrate staining. The strip pattern was digitally photographed for further scoring, examination and analysis.

\section{Table 2. Msel / EcoRI primer sequence used in selective PCR reaction}

\begin{tabular}{|llll|}
\hline Selective nucleotide end '3 & code & Selective nucleotide end '3 & code \\
\hline E-AAT/M-CAA & E & E-ACA/M-CCT & A \\
E-AAT/M-CAG & F & E-AAG/M-CTC & B \\
& & E-ACA/M-GGA & C \\
& & E-AGT/M-CCT & D \\
\hline
\end{tabular}

\subsection{Data analysis}

Mean and standard deviation were calculated with respect to field sampling parameters. One-way ANOVA was used to compare mean data at each station and Tukey test with $95 \%$ validity to determine differences between parameters. Correlation between parameters was calculated using Pearson correlation coefficient using SPSS22 software. For AFLP data analysis, bands were scored as present (1) or absent (0), and data were transferred to Excel software and various intra-population variability criteria were evaluated and calculated. Statistical analysis and genetic estimations of polymorphism, genetic diversity, Shannon index I, similarity and genetic distance based on Nei (Nei 1978), gene flow $\left(N_{m}\right)$, genetic differentiation (Fst) analysis of molecular variances (AMOVA) at 0.01 level were calculated among samples of 4 stations using GeneAlex software(Smouse and Peakall 2012). Generating and displaying charts was performed using Microsoft Excel 2016.

\section{Results}

\subsection{Mangrove Quality Index:}

The percentage of mangrove coverage based on Mangrove Quality Index is used for recording mangrove ecosystem overall health status. The results showed station 4 in southern part of the study area with code 5 (coverage percentage of $0-10 \%$ ) is in unhealthy condition and station 2 in north part of the estuary with a score of $2(51-75 \%$ coverage) was in a relatively healthy condition compared to other sampling stations. In addition, the results of mangrove restoration score showed that station 4 was found to have poor restoration score (5) and no mangrove propagules was observed in this area. 
The number of crab holes per unit area $\left(\mathrm{m}^{2}\right)$ varied at four sampling locations (Fig.2). The highest average number of crab holes per square meter was observed at station 2 (northern part) and the lowest was observed at station 4 (southern part). However, according to the scoring based on MQI, no significant difference between the number of crab holes was observed between stations and all stations scored 3 .

Basal area is a physical factor to compare and describe the characteristics of trees. The highest average level was observed at station 3 and the lowest at station 1 (northern estuary) However, based on the MQI scoring criteria, all stations were scored 1 (Fig.3).

Absolute density was calculated using pcqm data in a 100 square meter area. The highest absolute density was at station 4 (south estuary) (Fig.4). There was a significant difference between the absolute density of different stations $(P<0.05)$. Pearson correlation coefficient test showed that there was a significant relationship between basal level and absolute density at 0.01 level.

The primary production of seawater which is directly related to the concentration of phytoplankton in water was measured based on chlorophyll a. The results are presented in fig.5. The highest mean chlorophyll content was observed at station 4 and station 3 respectively. There was a significant difference between the mean chlorophyll contents $(p<0.05)$ of four stations. Mean turbidity at different stations was compared. The highest turbidity was observed at station 2 (northern estuary) (Fig.6). No significant correlation was observed between chlorophyll and water turbidity at 0.01 level.

The results of sediment grading analysis are shown in Figure7. Generally, the highest amount of coarse sand was observed at station 4 and station 3, respectively. In addition, coarse sand formed the major part of sediments throughout the study area. The results of organic content analysis showed that the highest amount of organic content was observed at station 2 in the north of Nayband and the lowest was observed at station 3 (Fig.8).

The land use around mangroves have a significant impact on their hydrological performance. The stations 1 (north estuary) and 4 (south estuary) have the highest MQI coding score indicating the highest human land use around the study area. The highest changes were observed at station 4 followed by station 3.

Based on the results of the criteria overall scores of MQI calculations are presented in table2. The station $2(\mathrm{MQI}=0.5)$ showed a relatively higher quality index compared to other areas and station 4 was in an unhealthy status compared to the other 3 stations (Table 3 ).

\section{Table 3. Summary statistics for MQI metrics in Nayband national park, Iran}




\begin{tabular}{|lllllllll|}
\hline $\begin{array}{l}\text { Station } \\
\text { number }\end{array}$ & $\begin{array}{l}\text { Number of } \\
\text { crab holes }\end{array}$ & $\begin{array}{l}\text { Basal } \\
\text { area }\end{array}$ & Turbidity & user & $\begin{array}{l}\text { changes } \\
\text { rate }\end{array}$ & $\begin{array}{l}\text { Mangrove } \\
\text { recriutment }\end{array}$ & $\begin{array}{l}\text { Percentage } \\
\text { of } \\
\text { coverage }\end{array}$ & MQI \\
\hline 1 & 3 & 1 & 5 & 5 & 2 & 4 & 3 & 0.6 \\
\hline 2 & 3 & 1 & 5 & 4 & 2 & 3 & 2 & 0.5 \\
\hline 3 & 3 & 1 & 3 & 4 & 4 & 5 & 3 & 0.6 \\
\hline 4 & 3 & 1 & 3 & 5 & 5 & 4 & 5 & 0.7 \\
\hline
\end{tabular}

\subsection{Genetic analysis}

\subsubsection{Allelic and heterozygous abundance}

A total of 40 Parasesarma persicum crab specimens were analyzed for DNA polymorphism based on AFLP marker. The overall results of the analysis are presented in Table4. The mean percentage of total polymorphism was $92.76 \%$ and the percentages of polymorphism were $97.20,95.33,93.46$ and 85.05 for populations Pop2, Pop3, Pop4, Pop1, respectively. Heterozygosity $(\mathrm{He})$ ranged from 0.29 to 0.32 with a mean of 0.30 . According to the analysis of genetic diversity of Parasesarma persicum at different sampling stations, the highest genetic diversity was observed in samples from the station 2 . The results of the Allelic Pattern (APT) showed (Fig.9) that the highest number of bands was observed in station 2 samples and the lowest in the station 1 . The highest genetic diversity is related to station 2 and the lowest is related to station 1 .

\subsubsection{Genetic variation in populations}

The number of effective Ne alleles indicates a polymorphism that is less sensitive to the sample. The lowest effective population alleles were calculated in station 4 and the highest in station 2 . The measure of genetic diversity in each population is determined by the Shannon I index. Therefore, the lowest Shannon index is related to Station 1 and the highest population is related to Station 2 (table 4).

\section{Table 4. Comparison of genetic diversity indices in 4 populations}




\begin{tabular}{|llllllll|}
\hline uHe & $\mathrm{He}$ & $\mathrm{I}$ & $\mathrm{Ne}$ & $\mathrm{Na}$ & $\mathbf{N}$ & & Pops \\
\hline $0 / 314$ & $0 / 298$ & $0 / 446$ & $1 / 509$ & $1 / 720$ & $10 / 000$ & mean & $\mathbf{1}$ \\
\hline $0 / 018$ & $0 / 017$ & $0 / 023$ & $0 / 034$ & $0 / 066$ & $0 / 000$ & $\mathrm{SE}$ & \\
\hline $0 / 321$ & $0 / 321$ & $0 / 488$ & $1 / 531$ & $1 / 944$ & $10 / 000$ & mean & $\mathbf{2}$ \\
\hline $0 / 013$ & $0 / 013$ & $0 / 017$ & $0 / 029$ & $0 / 032$ & $0 / 000$ & $\mathrm{SE}$ & \\
\hline $0 / 328$ & $0 / 312$ & $0 / 474$ & $1 / 519$ & $1 / 907$ & $10 / 000$ & mean & $\mathbf{3}$ \\
\hline $0 / 015$ & $0 / 014$ & $0 / 018$ & $0 / 030$ & $0 / 041$ & $0 / 000$ & $\mathrm{SE}$ & \\
\hline $0 / 315$ & $0 / 299$ & $0 / 456$ & $1 / 499$ & $1 / 879$ & $10 / 000$ & mean & $\mathbf{4}$ \\
\hline $0 / 016$ & $0 / 015$ & $0 / 020$ & $0 / 032$ & $0 / 045$ & $0 / 000$ & $\mathrm{SE}$ & \\
\hline $0 / 324$ & $0 / 307$ & $0 / 466$ & $1 / 515$ & $10 / 000$ & $10 / 000$ & mean & Total \\
\hline $0 / 008$ & $0 / 008$ & $0 / 010$ & $0 / 016$ & $0 / 000$ & $0 / 000$ & SE & \\
\hline
\end{tabular}

\subsubsection{Principal Component Analysis (PCA)}

The principal coordinates based on the results of genetic analysis was used to explain differences among the examined crab sample individuals (Fig.9). In spite of overall differences between most of individuals of station 1 and 4 no complete population differentiation was observed.

One of the multivariate methods that provides useful information on the differentiation of major groups and groups them based on similarity coefficients between data is principal component analysis (PCA). PCA diagram drawn to study the relationships between stations (Fig.10). The results showed high overlap between populations 1,2 and 3 , but population 4 is more differentiated.

\subsubsection{Differences in genetic variation within and between populations based on the AMOVA test}

Analysis of Molecular Variances(AMOVA) is a method for estimating population differentiation among a species. The analysis performed based on 4 sampled stations, 2 areas northern (1and 2) and southern(3 and 4). The results of AMOVA attributed most of genetic variances (93\%) to intrapopulation differences, while $2 \%$ of variances could be attributed to between stations variability and low(5\%) but significant differentiation was calculated among the studied regions (Fig.11).

Nei's genetic differentiation coefficient $\left(\mathrm{F}_{\mathrm{st}}\right)$ showed highest genetic differentiation between crab samples from station 1 and 4(0.125), where the lowest gene flow $(\mathrm{Nm})$ of 1.74 individual per generation was calculated. Highest gene flow of 36.91 and lowest genetic differentiation $\left(F_{s t}\right)$ of 0.007 was estimated between samples from station 1 and 3 .

\subsection{Correlation between Mangrove Quality Index and Genetic Diversity of Crab Parasesarma persicum}


The results of statistical analysis showed a significant positive correlation between mangrove quality index (MQI) and genetic diversity which shows low mangrove quality correlated to decrease in genetic diversity of Parasesarma persicum.

\section{Discussion}

\section{1. mangrove health:}

Mangrove forest are from the most important ecosystems in the world as referred as the keystone of coastal ecosystem. They protect shoreline from storms, waves and hurricanes and prevent the erosion of the coastal line. Mangrove trees entrap pollutants and sediments from runoffs and maintain water clarity and quality. They provide habitat and nursery ground for many ecologically and commercially important marine species. Mangrove values were not fully understood until recent decades, and they have been negatively impacted by different human activities.

Nayband mangroves as one of the most important biosphere reserves and marine sensitive areas in the Persian Gulf play important role as habitat and nursery ground for many coastal vegetation, benthic animals, coastal birds and fish species. Global climate change in addition to local industrialization affected the health and viability of mangrove species. Therefore, application of a rapid and simple assessment system is critical for monitoring their health and observation of the degree of anthropogenic activities in short and longtime management programs.

The amount of human degradation have been measured by physical and environmental indices in the mangroves. Mangrove quality index(MQI) have been developed exclusively for easy and rapid assessment of habitat alteration of mangrove forests. The physical and biological characteristics of mangrove environment reflect their habitat performance, thus human impacts on mangroves could be assessed by measuring these characteristics. Biota, hydrologic condition, neighboring land use, mangrove density are easy scorable indices which indicates the degree of human impact on mangrove forest. The Mangrove Quality Index was formulated to reflect the overall mangrove health status. The results obtained from the present study confirmed usefulness of MQI components in assessment of the degree of disturbance in mangrove forests.

The highest percentage of mangrove coverage and Mangrove quality index score were observed at station 2 and the lowest at station 4 . This shows highest human negative impact at station 4 . Bridge construction in Basatin estuary(station4) resulted in disturbance in the hydrological cycle and consequent decrease in the percentage of cover, diameter and height of the mangrove trees. It has been reported that the regeneration of trapped trees in disturbed estuaries is impaired(Bosire et al. 2003). This theory has been confirmed by other researchers in the study area(Ziaeinejad, S. and Golmehdi 2014; Gandomi 2017).

The results of the present study showed that the average number of crab holes per area was higher at station 2 (northern estuary) and the lowest average was observed at southern estuary (station 4) (Fig. 2). 
Some studies have shown(Kathiresan and Bingham 2001; Tang et al. 2007) the distribution and presence of crabs is likely to depend on the presence and absence of mangrove trees, and any change in the ecosystem structure of mangrove organisms may alter the population structure of crabs. The low number of crab holes at station 4 may be attributed to the severe human impact, which disrupts hydrological flows and reduces the growth and density of mangrove trees.

In the present study, station 3 was scored 5 (disturbed) in terms of mangrove recruitment ability index. Drought stress leads to the absence of seedlings. The lack of propagules in this area (station 3) could be attributed to the crossing of the coastal road and disruption of hydrological flows in the area. The results of this study are consistent with the findings of Smith(1987) as well as Ziaeinejad and Golmehdi (2014).

The highest absolute density was observed in the southern estuary (Fig.4). Apparently factors such as road construction on the south side of the estuary and access road to the Persian Gulf International Airport on the east and north sides. reduced the growth of mangrove trees in this part of estuary. Erfani et al.(2009) reported that there is a positive and significant correlation between increasing tree density per hectare and tree height, crown diameter and trunk diameter and a positive and significant correlation between tree height and canopy percentage.

The highest basal area index was observed at station 3 and the lowest at station 4 (Fig.3). The basal area of the tree is directly related to environmental conditions and increases in correlation to optimum parameters. However, the closeness of Station 1 to the Assaluyeh River and discharge of municipal and industrial wastewater in this area appears to be a reason for the low basal area index at this station as suggested by former studies(Valipour Kahrood et al. 2007; Parvinia and Khamechian 2009; Ghasemian and Baziar 2010). Various studies on the structure of mangroves have also found a significant difference in the basal area of mangroves that are affected by human and natural activity. Hydrology plays an important role in wetland performance. In this study, chlorophyll and turbidity were evaluated as criteria indicating the mangrove environment status. The present results showed that the highest mean turbidity was observed at the northern stations (station1 and 2) (Fig.6). Chlorophyll is an index of primary production in an area and plays an important role in the ecological properties of an organism's ecosystem. The results showed that the highest amount of water chlorophyll was at the southern station (station4) (Fig.5). Chlorophyll content is influenced by several factors such as water quality, turbidity and composition of phytoplankton, temperature, tide, currents, light intensity, etc.

The northern area (station 1 and 2) is placed where many industrial and domestic wastewater is discharged regularly and occasionally overnight. Hydrological disturbers such as construction of bridge and road in the estuary increased the degree of turbidity due to low water exchange with sea. Similar observation of increasing turbidity and low primary production due to hydrological disturbance have been reported by Whigham (1999), and Davari et al. (2010).

Based on sediment gradation analysis, the coarse sand percentage was higher than $40 \%$ in all stations. Station 4 in the southern estuary had the highest coarse sand percentage and the lowest mud percentage. In addition, the highest percentage of mud was observed at station 1. Almost all studies of 
mangrove habitats have yielded similar sediment gradation results(Tehrani et al. 2016; Zahedi et al. 2019).

Mangrove sediments are composed of organic matter, minerals and wastewater. Total organic matter deposition (TOM) the ratio of organic matter in sediments depends on the type of substrate. Organic matter is a value showing the productivity of sediment in addition to the role of organic matter in adhesion of sediment and lowering interasediment spaces(Knox and Kilham 2000). The sediments are the final destination of many contaminants that can reflect the pollution condition of the area. In the present study, the percentage of organic matter was higher at station 2 and 1 (northern estuary, respectively). Since these two stations contain muddy grains and fine grains, they have the greater potential to confine organic and inorganic pollutants to the water column. which can confirm the high organic matter content at these stations. Factors such as seasonal disturbance, physical conditions caused by current flows and on the other hand human interference, petroleum pollutants can alter the amount of organic matter in the environment of coastal environment. Particularly in sediments.

\subsection{Mangrove Quality Index}

The mangrove quality index is a useful and effective tool for managing the mangrove ecosystem, ensuring rapid evaluation for their protection. MQI can be used as part of the decision making process for new projects or monitoring of mangrove ecosystems. The MQI value ranges between 0-1 wherase 1 is the most adversely affected by human activities and 0 is the most undisturbed mangrove ecosystem. Based on the results of the present study, this value was calculated between 0.5 and 0.7 for the study area. The highest MQI (0.7) was observed at station 4 (high human impact) and the lowest was for station 2.

Station 4 mangroves subjected to direct impact of human activities. Human constructions affected hydrological condition of estuary and consequent physical and chemical changes of the mangrove environment. The effects of water quality on growth of mangroves has been evidence in literature(Peters et al. 2020). Chen et al.(2016) reported a 44 percent decline in mangrove area in China from 1950 to 2001 , as a result of urbanization, surface erosion caused by agriculture and aquaculture, oil pollution and land use change. Tuffers et al. (2001) also stated that the Durban Bay mangrove drought caused by the closure of estuaries in South Africa reduced soil salinity in closed estuaries and weakened trees due to reduced levels of photosynthesis and sodium deficiency of calcium and chlorine in the leaves of trees. The MQI 0.7 (inappropriate quality status) of Station 4 confirms these results due to the establishment of Imam Ali Bridge and road construction which disrupted the hydrological cycle.

\subsection{AFLP analysis of crabs}

The results of genetic examinations showed that the highest mean of genetic diversity was at station 2 (0.321) and the lowest was at station 1 (0.298) and 4 (0.229). The highest heterozygosity and percentage of polymorphism was observed in station 2 samples, indicating higher diversity. Environmental stresses, degradation of natural habitats might result in genetic bottlenecks leading to reduced 
heterozygosity(Norris et al. 1999). Previous studies reported positive correlation between the concentration of crabs and the mangrove trees(Kathiresan and Bingham 2001; Tang et al. 2007).

Analysis of molecular variance (AMOVA) showed that most of the genetic diversity (93\%) resulted from the variation among individuals and no significant difference $(P>0.01)$ between stations samples. Some genetic differences were calculated between samples from station 4 and other stations based on PCA analysis, however, no complete population structuring was observed based on the studied marker. Observed differentiations between samples from station 4 and other samples might be attributed to recently relative spatial separation as the result of construction of Imam Ali bridge. Anthropogenic activities may affect spawning and nesting and feeding of animals and alter their habitats, resulting in decreased genetic diversity and in some cases creating different populations in some isolated habitats within a limited geographical area(Xu et al. 2011).

\subsubsection{Population structure of the crab Parasesarma persicum in the Mangrove Neybend organism}

Gene flow is the main factor in genetic differentiation of connected populations. In the present study, high gene flow in the four stations(average $=12.4$ ) was predictable based on proximity of the stations and the water connection. However, relatively lower gene flow and high genetic differentiation (Fst) between stations 4 and other samples may explain by low hydrological flow and connection as the result of bridge construction on $1.5 \mathrm{~m}$ diameter pipes at station 4. Higher contamination in some studies at station 4 may also be involved. Davari et al. (2010) have pointed to the role of heavy metals at station 4 (due to the closure of the hydrological cycle) in the pollution of this area.

\subsection{The effect of mangrove disturbance on genetic diversity of crab Parasesarma persicum}

Few studies have reported the effect of structural disturbance of mangroves on the genetic diversity of their benthic fauna(Skilleter and Warren 2000; Ngo-Massou et al. 2018). Studies on molecular consequences of human disturbance in mangroves are scarce. Inefficient conservation practices in the management of mangroves have been attributed to low species richness and diversity indices of carbs in Cameroon mangrove forests. Skilleter et al., reported change in species composition of mollusks and crabs of disturbed area in contrast to reference area of mangroves in Moreton Bay(Skilleter and Warren 2000). M'rabu evidenced decreased diversity of crabs in El-Niño impacted sites in contrast to reference sites(Jenoh 2009).

The results of the present study showed that the mangrove areas which most affected by human activities represent lower genetic diversity and heterozygosity of mangrove crab Parasesarma persicum. The results showed that Station 4 had the lowest gene diversity and the highest habitat degradation. Significant positive correlation was observed between the heterozygosity-based genetic diversity of $P$. persicum crab and mangrove quality index in the studied area. The present study confirmed the impact of habitat degradation on reducing the quality of mangroves and reducing the genetic diversity of their dependent species. 


\section{Conclusion}

The results presented here shows that MQI can be implemented as an effective rapid tool for ecosystem health assessment and monitoring the human activities impacts on mangroves. Medium to low quality of mangrove was observed at the study area. The anthropogenic alterations of mangrove ecosystem resulted in decreasing mangrove health followed by reduction in genetic diversity of dependent crab species.

\section{Declarations}

\section{Acknowledgements}

The authors would like to thank Farshid Heidary for his kind assist in sampling as well as Dr. Ali Fakhri and other Persian Gulf Studies Institute stuff for their kind assistance during the sampling and examinations, the General Manager and personnel of Department of Environment of Bushehr Province for permission given to us to for sampling in the Nayband national park.

\section{Funding}

The authors declare that the research did not have received funding and there is no conflict of interest.

\section{Conflicts of interest}

Not applicable

\section{Ethics approval}

Not applicable

\section{Consent to participate}

Not applicable

\section{Consent for publication}

Not applicable

\section{Availability of data and material}

Not applicable

\section{Authors' contributions}

M D has participated in field sampling (mangrove measurements and observations, water, and sediment samplings) lab analysis and preparation of manuscript. A S conducted and participated the sampling, 
identification and DNA extraction of crabs and initial study of the studied area as well as water, and sediment sampling in addition to final edit and correspondence of manuscript. Y G designed the sampling of mangroves, including primary observations of the studied area, selection of the stations and analysis of quality indices and its relevant criteria. A $G$ was the main researcher for genetic analysis and performed AFLP analysis for sampled crabs. All authors read and approved the final manuscript.

\section{References}

Abbaszadeh T (2016) Introducing a method for ecosystem health assessment based on remote sensing technologies. Environ Res 6:71-84

Bagley MJ (2002) Genetic diversity as an indicator of ecosystem condition and sustainability [microform]

Bosire JO, Dahdouh-Guebas F, Kairo JG, Koedam N (2003) Colonization of non-planted mangrove species into restored mangrove stands in Gazi Bay, Kenya. Aquat Bot 76:267-279

Chen G, Chen B, Yu D, et al (2016) Soil greenhouse gases emissions reduce the benefit of mangrove plant to mitigating atmospheric warming effect. Biogeosciences Discuss 1-22

Dahdouh-Guebas F, Jayatissa LP, Di Nitto D, et al (2005) How effective were mangroves as a defence against the recent tsunami? Curr Biol 15:R443-R447

Davari A, Danehkar A, Khorasani N, Javanshir A (2010) An investigation on accumulation of heavy metals in roots and leaves of Avicennia marina the sediment, Bushehr, the Persian Gulf. J Nat Environ 63:267-277

Ellison JC, Zouh I (2012) Vulnerability to climate change of mangroves: assessment from Cameroon, Central Africa. Biology (Basel) 1:617-638

Erfani M, Nouri G, Danekar A, et al (2009) Vegetative parameters of mangrove forest on the Govater bay in southeast of Iran. Taxon Biosyst 1:33-46

Faridah-Hanum I, Yusoff FM, Fitrianto A, et al (2019) Development of a comprehensive mangrove quality index (MQI) in Matang Mangrove: Assessing mangrove ecosystem health. Ecol Indic 102:103-117

Fratini S, Zane L, Ragionieri L, et al (2008) Relationship between heavy metal accumulation and genetic variability decrease in the intertidal crab Pachygrapsus marmoratus (Decapoda; Grapsidae). Estuar Coast Shelf Sci 79:679-686

Gandomi Y (2017) Change Detection and Health Assessment of Nayband Mangroves. Khorramshahr University of Marine Sciences and Technology, Khoramshahr

Ghasemian M, Baziar M (2010) Pars energy special economic zone and its impact on mangrove forest ecosystem in nayband bay,. In: Fourth Specialized Conference on Environmental Engineering. Tehran, pp 
Ibrahim S, Faridah-Hanum I, Hakeem KR (2016) development of Mangrove Quality Index (MQI)) in Malaysia: a Proposal. Malaysian For 79:197-202

Jenoh EM (2009) The impact of indirect effects of climate change on mangrove associated biodiversity. Vrije Univ Brussels Vrije Univ Brussels

Kathiresan K, Bingham BL (2001) Biology of mangroves and mangrove ecosystems. Adv Mar Biol 40:84254

Knox, K.Kilham C and L (2000) effects of increased nitrate availability on the control of plant pathogenic fungi by the soil bacterium bacillus subtilis. Appl soil Ecol 15:227-231

Lindquist ES, Krauss KW, Green PT, et al (2009) Land crabs as key drivers in tropical coastal forest recruitment. Biol Rev 84:203-223

Ling Q, Li S, Li Z (2009) Genetic structure of the Hatchery and wild Scylla Paramamosain populations using RAPD and AFLP techniques. In: 2009 International Conference on Environmental Science and Information Application Technology. IEEE, pp 43-46

McIntyre AD, Eleftheriou A (2005) Methods for the study of marine benthos. Blackwell Science

Mirimin L, Roodt-Wilding R (2015) Testing and validating a modified CTAB DNA extraction method to enable molecular parentage analysis of fertilized eggs and larvae of an emerging South African aquaculture species, the dusky kob Argyrosomus japonicus. J Fish Biol 86:1218-1223

Mueller-Dombois D, Ellenberg H (1974) Aims and methods of vegetation ecology. Wiley Naderloo R (2017) Atlas of crabs of the Persian Gulf. Springer

Nei M (1978) Estimation of average heterozygosity and genetic distance from a small number of individuals. Genetics 89:583-590

Nelson DW, Sommers LE (1996) Total carbon, organic carbon, and organic matter. Methods soil Anal Part 3 Chem methods 5:961-1010

Ngo-Massou VM, Din N, Kenne M, Dongmo AB (2018) Brachyuran crab diversity and abundance patterns in the mangroves of Cameroon. Reg Stud Mar Sci 24:324-335

Norris AT, Bradley DG, Cunningham EP (1999) Microsatellite genetic variation between and within farmed and wild Atlantic salmon (Salmo salar) populations. Aquaculture 180:247-264

Parvinia M, Khamechian S (2009) Investigation of south pars phases 6, 7 and 8 treatment plant by PRB method, and coastal water pollution caused by different activities of pars energy special economic zone. 
Peters R, Walther M, Lovelock C, et al (2020) The interplay between vegetation and water in mangroves: new perspectives for mangrove stand modelling and ecological research. Wetl Ecol Manag 28:697-712 Skilleter GA, Warren S (2000) Effects of habitat modification in mangroves on the structure of mollusc and crab assemblages. J Exp Mar Bio Ecol 244:107-129

Smith RD, Wakeley JS (2001) Hydrogeomorphic approach to assessing wetland functions: Guidelines for developing regional guidebooks. Chapter 4, Developing assessment models

Smith TJ (1987) Effects of light and intertidal position on seedling survival and growth in tropical tidal forests. J Exp Mar Bio Ecol 110:133-146

Smouse RPPE, Peakall R (2012) GenAlEx 6.5: genetic analysis in Excel. Population genetic software for teaching and research-an update. Bioinformatics 28:2537-2539

Spalding MD, Kainuma M, Collins L (2010) World Atlas of Mangroves; Earthscan with ITTO, ISME, FAO, UNEP-WCMC

Su M, Fath BD, Yang Z (2010) Urban ecosystem health assessment: A review. Sci Total Environ 408:2425-2434

Sutula MA, Stein ED, Collins JN, et al (2006) A practical guide for the development of a wetland assessment method: The California experience 1. JAWRA J Am Water Resour Assoc 42:157-175

Takezaki N, Nei M (1996) Genetic distances and reconstruction of phylogenetic trees from microsatellite DNA. Genetics 144:389-399

Tang W, Zheng M, Zhao X, et al (2018) Big geospatial data analytics for global mangrove biomass and carbon estimation. Sustainability 10:472

Tang Y, Yu S, Wu Y (2007) A comparison of macrofauna communities in different mangrove assemblages. Zool Res 28:255-264

Tanksley SD, Orton TJ (2012) Isozymes in plant genetics and breeding. Elsevier

Tehrani GM, Sany SBT, Hashim R, Salleh A (2016) Predictive environmental impact assessment of total petroleum hydrocarbons in petrochemical wastewater effluent and surface sediment. Environ Earth Sci $75: 177$

Tuffers A, Naidoo G, Von Willert DJ (2001) Low salinities adversely affect photosynthetic performance of the mangrove, Avicennia marina. Wetl Ecol Manag 9:235-242 
Valipour Kahrood H, Korori A, Danehkar A, Shirvani A (2007) Changes in Peroxidase Isozymes in Mangrove Species (Avicennia marina) After Exposure to Heavy Metals and Oil Pollutants. Iran Biol 20:257-268

Vos P, Hogers R, Bleeker M, et al (1995) AFLP: a new technique for DNA fingerprinting. Nucleic Acids Res 23:4407-4414

Whigham DF (1999) Ecological issues related to wetland preservation, restoration, creation and assessment. Sci Total Environ 240:31-40

Wilson MS (2009) Development of a Mangrove Quality Index in Tampa Bay, Florida

Xu Q, Chen F, Shin PKS, et al (2011) AFLP analysis of genetic variation among three natural populations of horseshoe crab Tachypleus tridentatus along Chinese coast. Chinese J Oceanol Limnol 29:284-289

Zahedi D, Gheshlaghi A, Mortazavi MS (2019) Assessment of total petroleum hydrocarbons and heavy metals in coastal sediments of hara forests in tiab region of hormozgan province. Stratigr Sedimentol Res 35:73-90

Ziaeinejad, S. and Golmehdi S (2014) effects and consequences of human activities on aquatic species and coastal habitats of nayband national park. J Environ Sci Eng 57:45-54

\section{Figures}




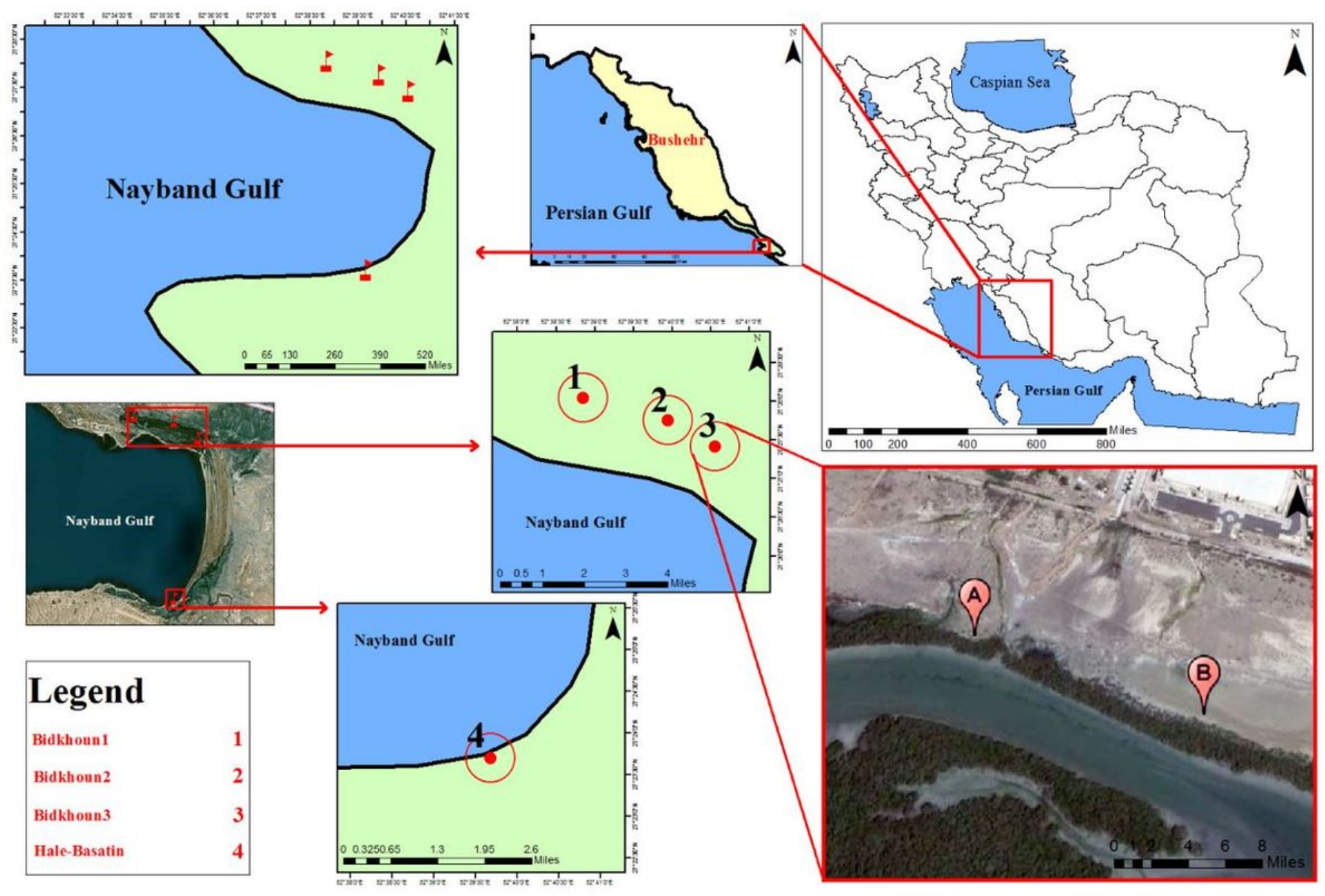

\section{Figure 1}

The location of the study area and 4 sampling stations in Nayband marine national park, Persian Gulf, Iran. Note: The designations employed and the presentation of the material on this map do not imply the expression of any opinion whatsoever on the part of Research Square concerning the legal status of any country, territory, city or area or of its authorities, or concerning the delimitation of its frontiers or boundaries. This map has been provided by the authors. 


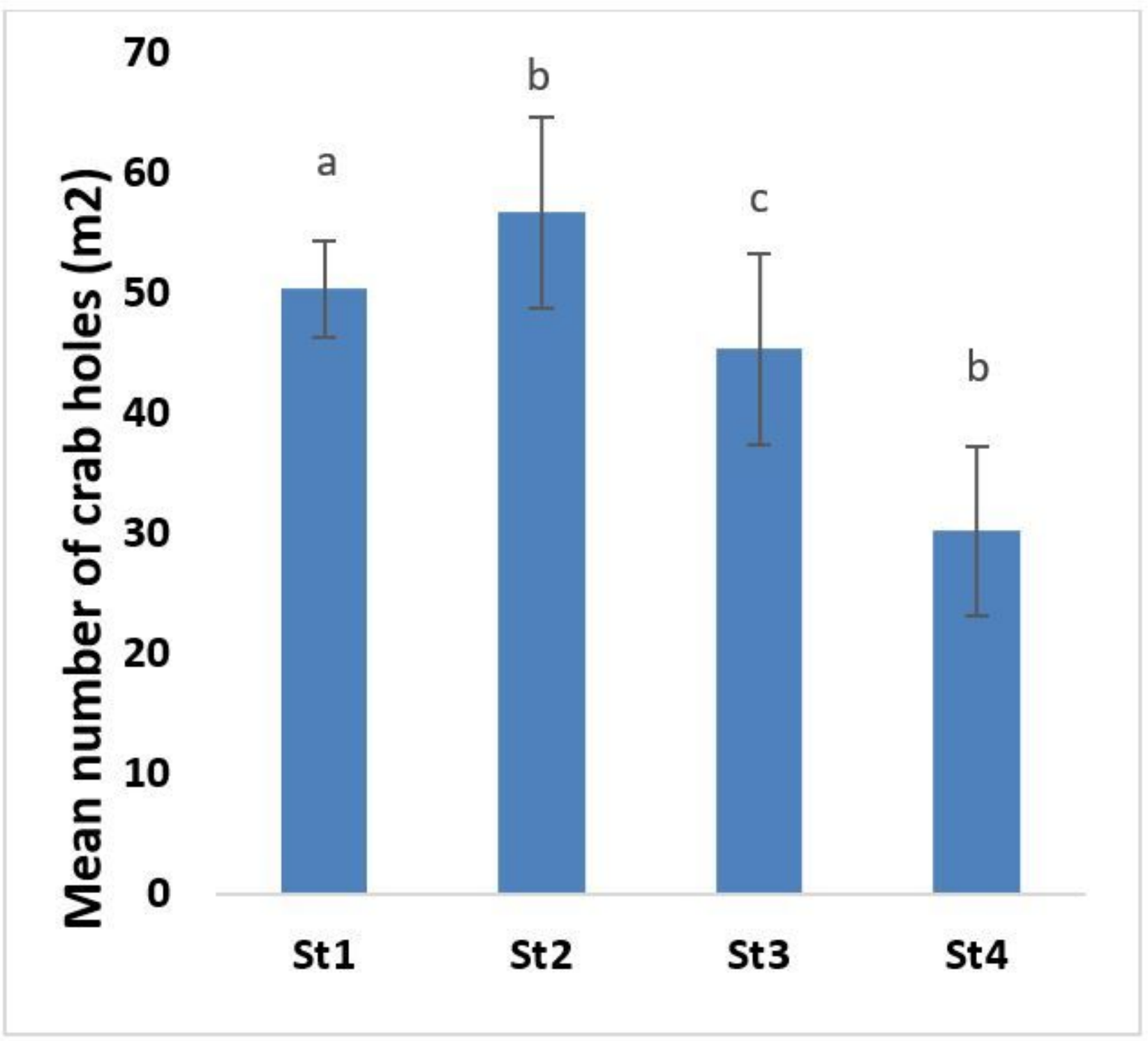

Figure 2

Comparison diagram of mean number of holes created by crabs at 4 sampling stations. 


\section{0}

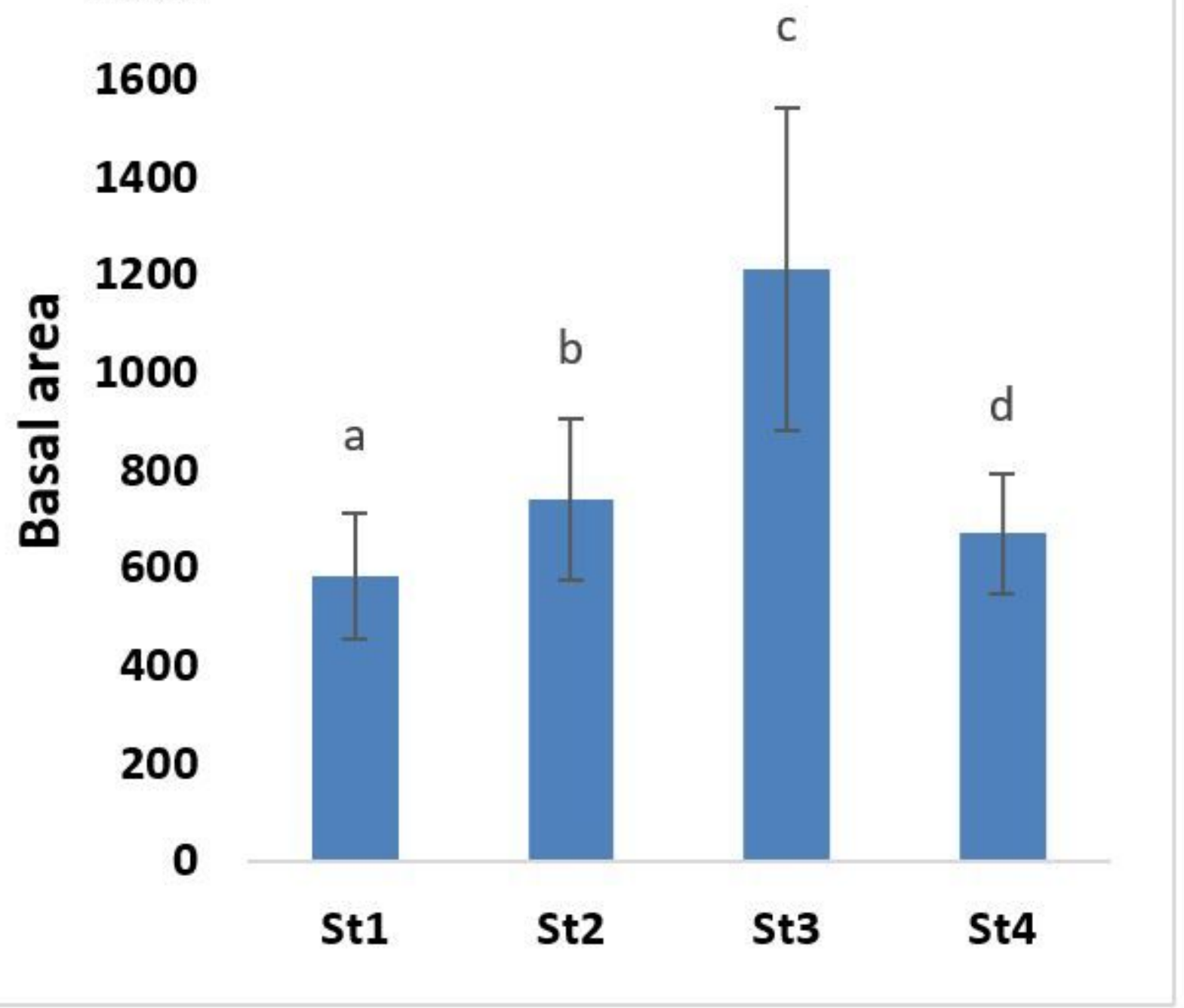

Figure 3

Comparison chart of the Mean Basal area at 4 stations in the study area. 


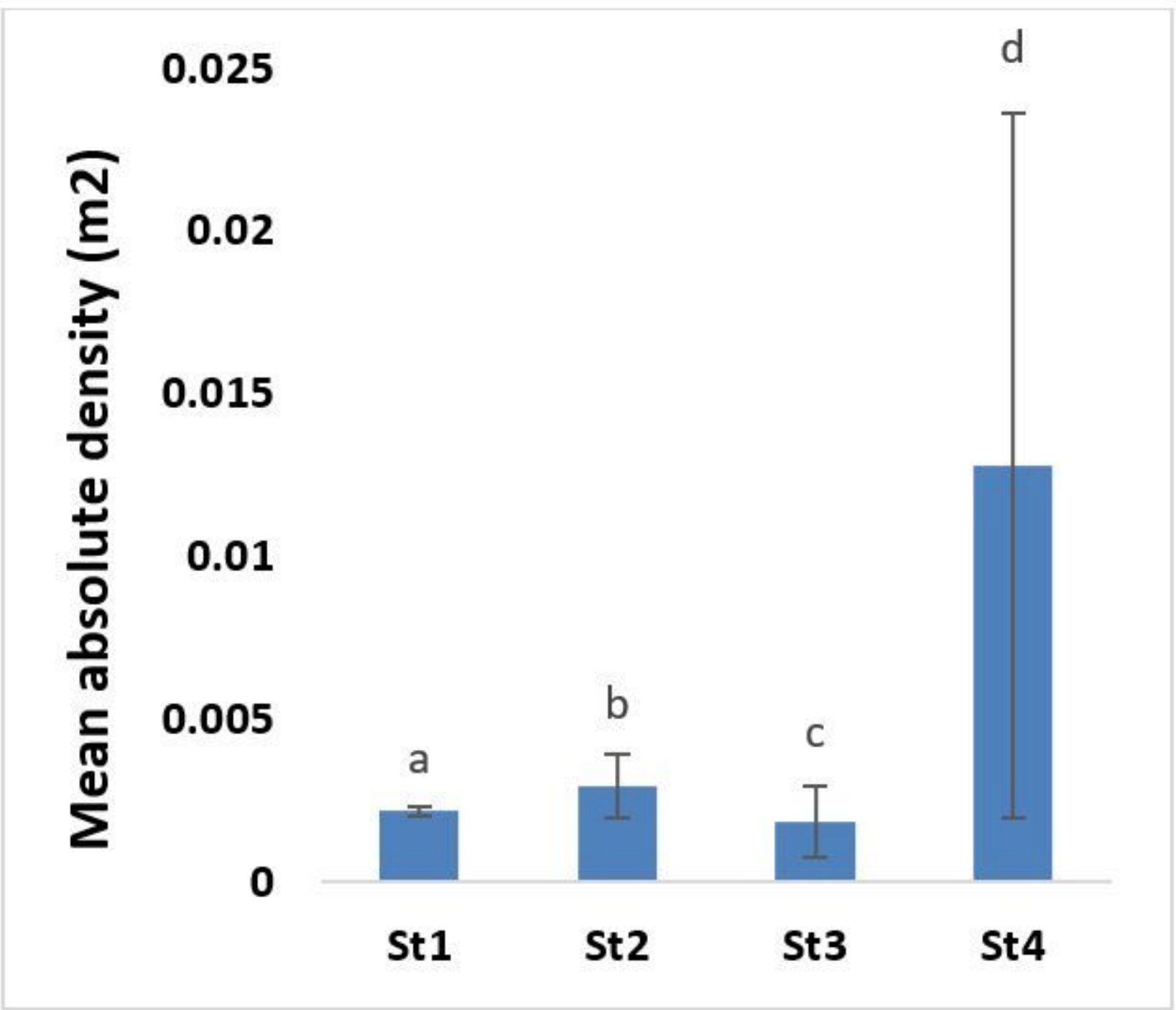

Figure 4

Comparison diagram of Mean absolute density at 4 stations in the study area. 


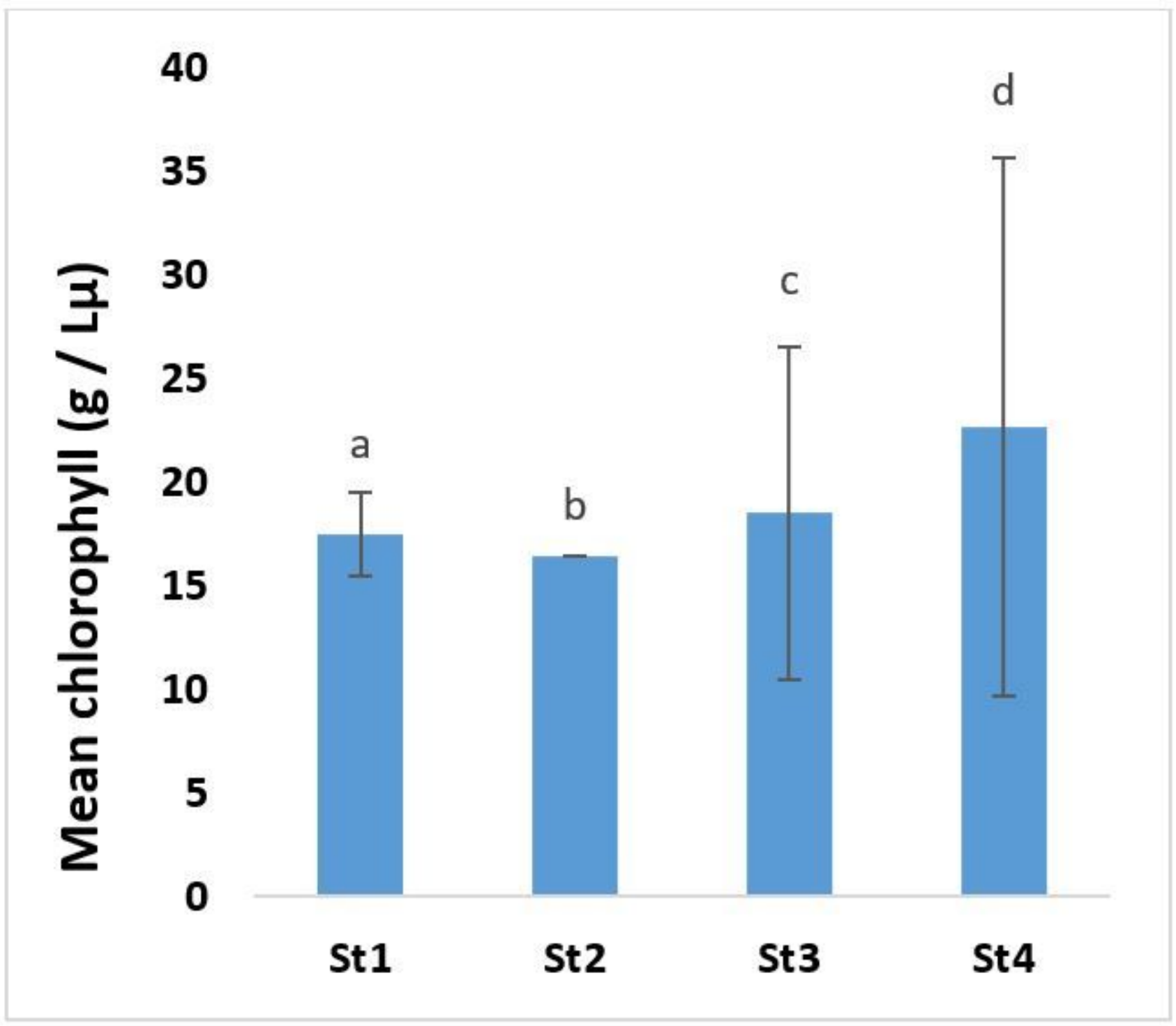

Figure 5

Diagram of Mean chlorophyll water of sampling stations in the study area. 


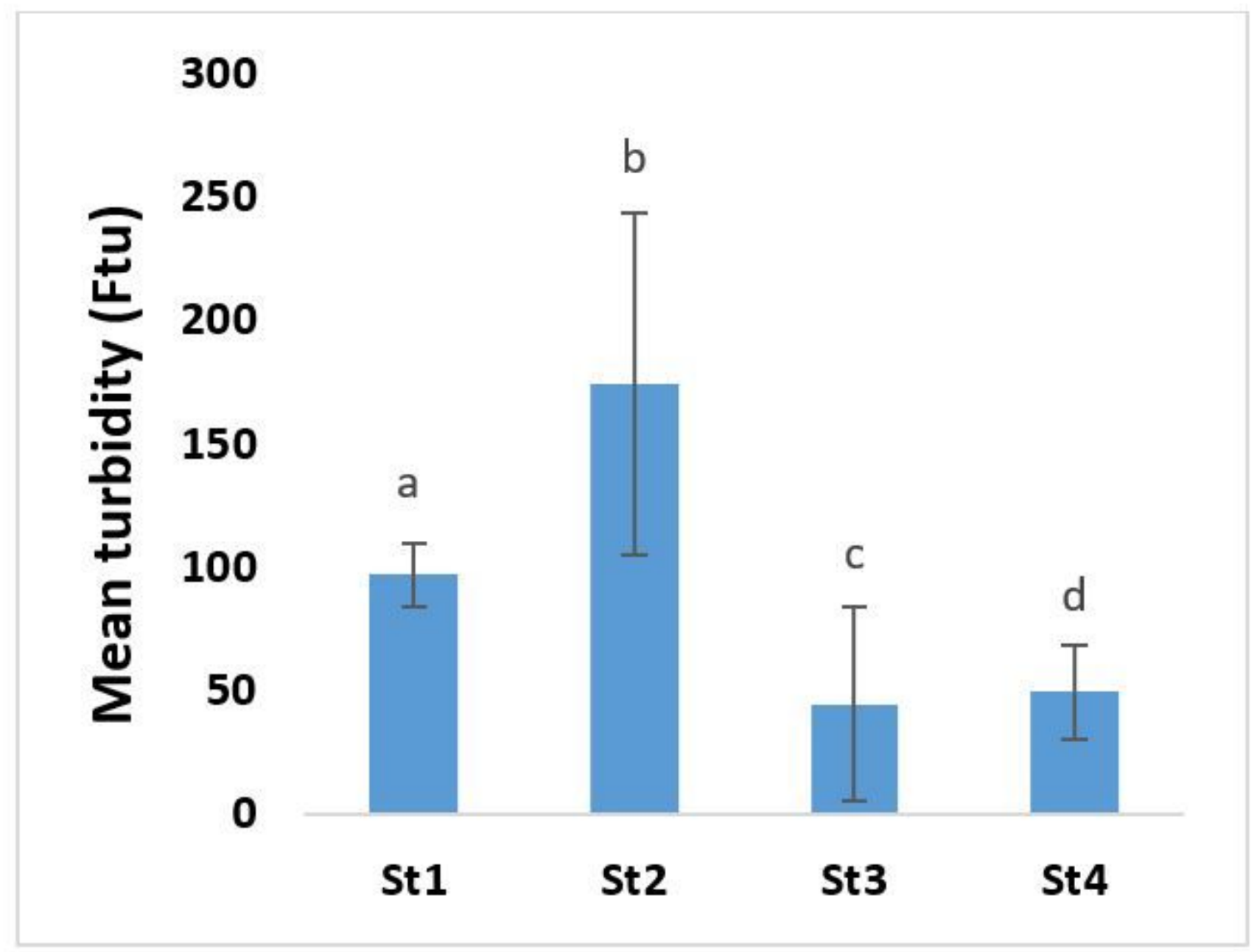

Figure 6

Diagram of Mean water turbidity in 4 stations in the study area. 


\section{Sediment grading}

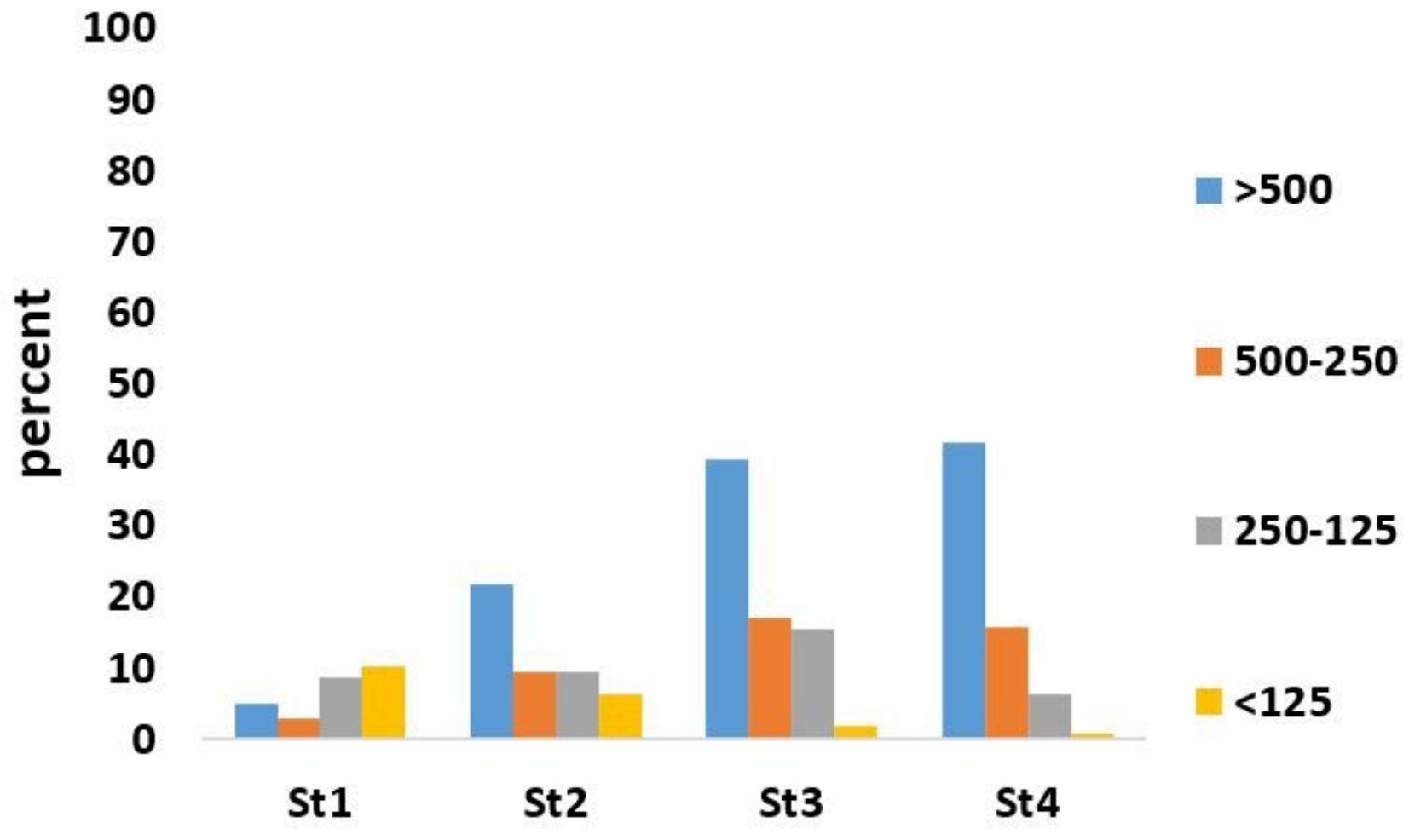

Figure 7

Sediment grading analysis in 4 studied stations in the study area. 


\section{0}

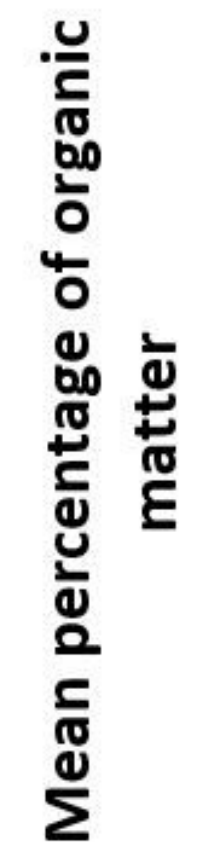

10

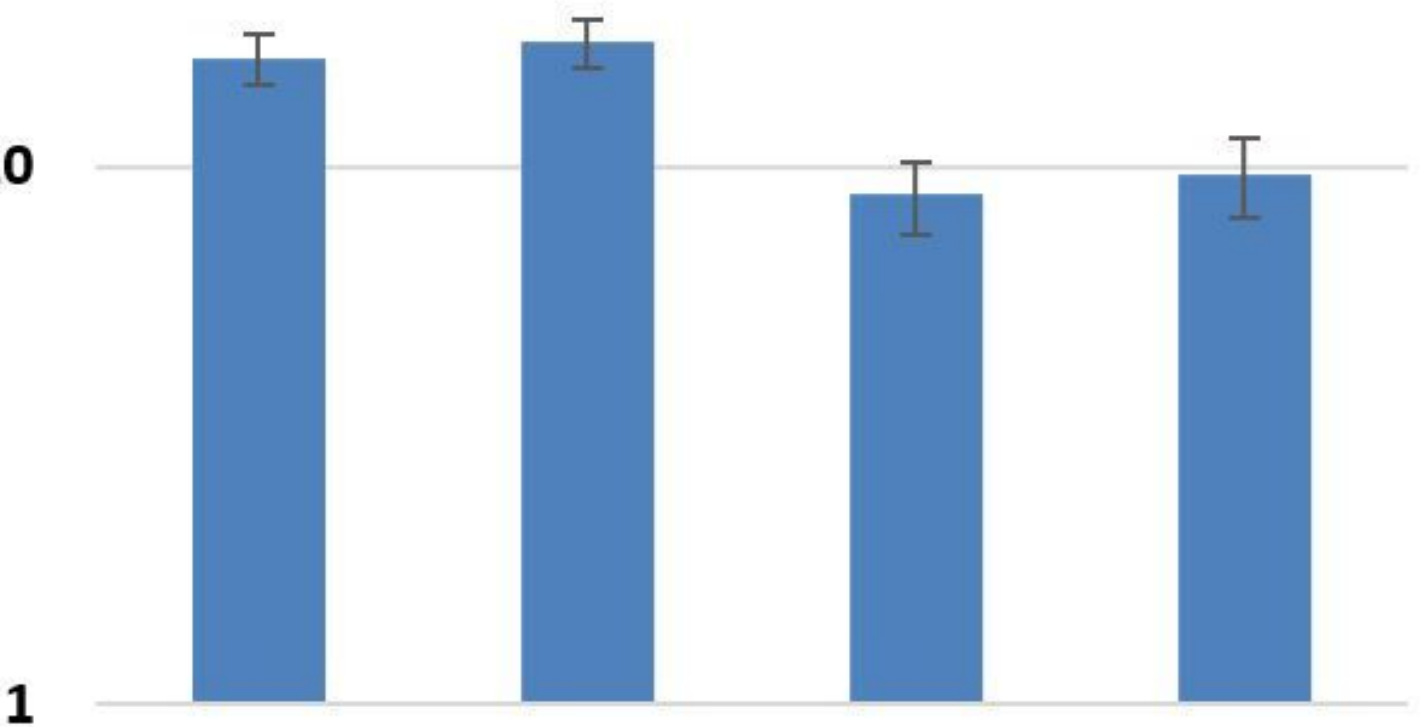

St 1

St 2

St 3

St 4

Figure 8

Results of the amount of organic matter in the 4 stations in the study area

No. Bands

No. Bands Freq. $>=5 \%$

No. Private Bands

No. LComm Bands (<=25\%)

No. LComm Bands (<=50\%)

$\longrightarrow$ Mean $\mathrm{He}$

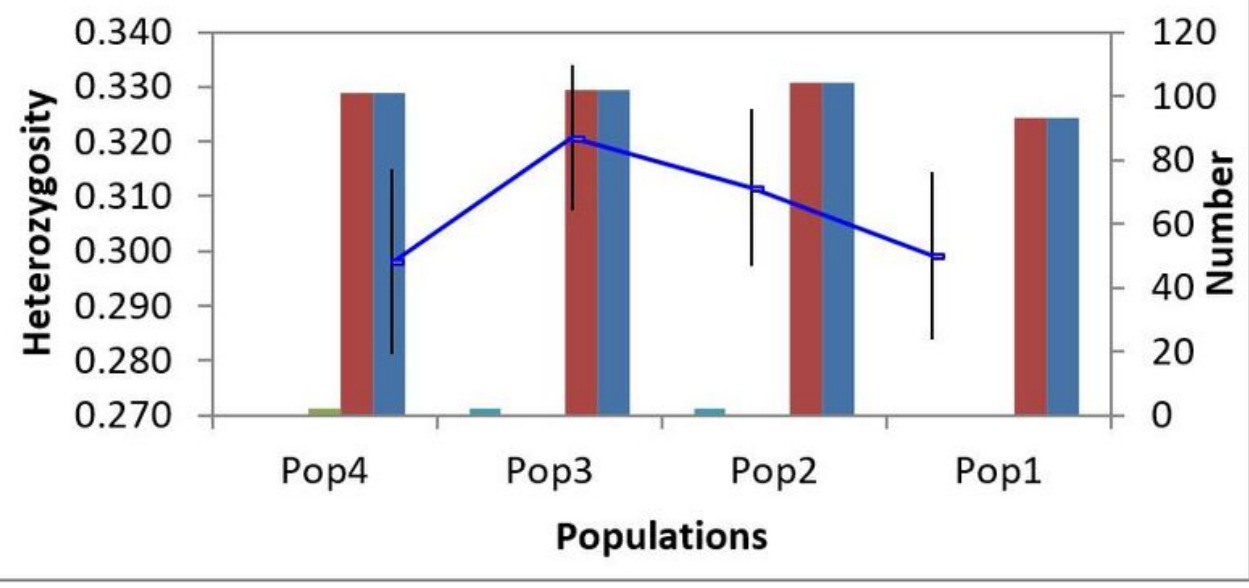

Figure 9

Band pattern of crabs in sampling stations 


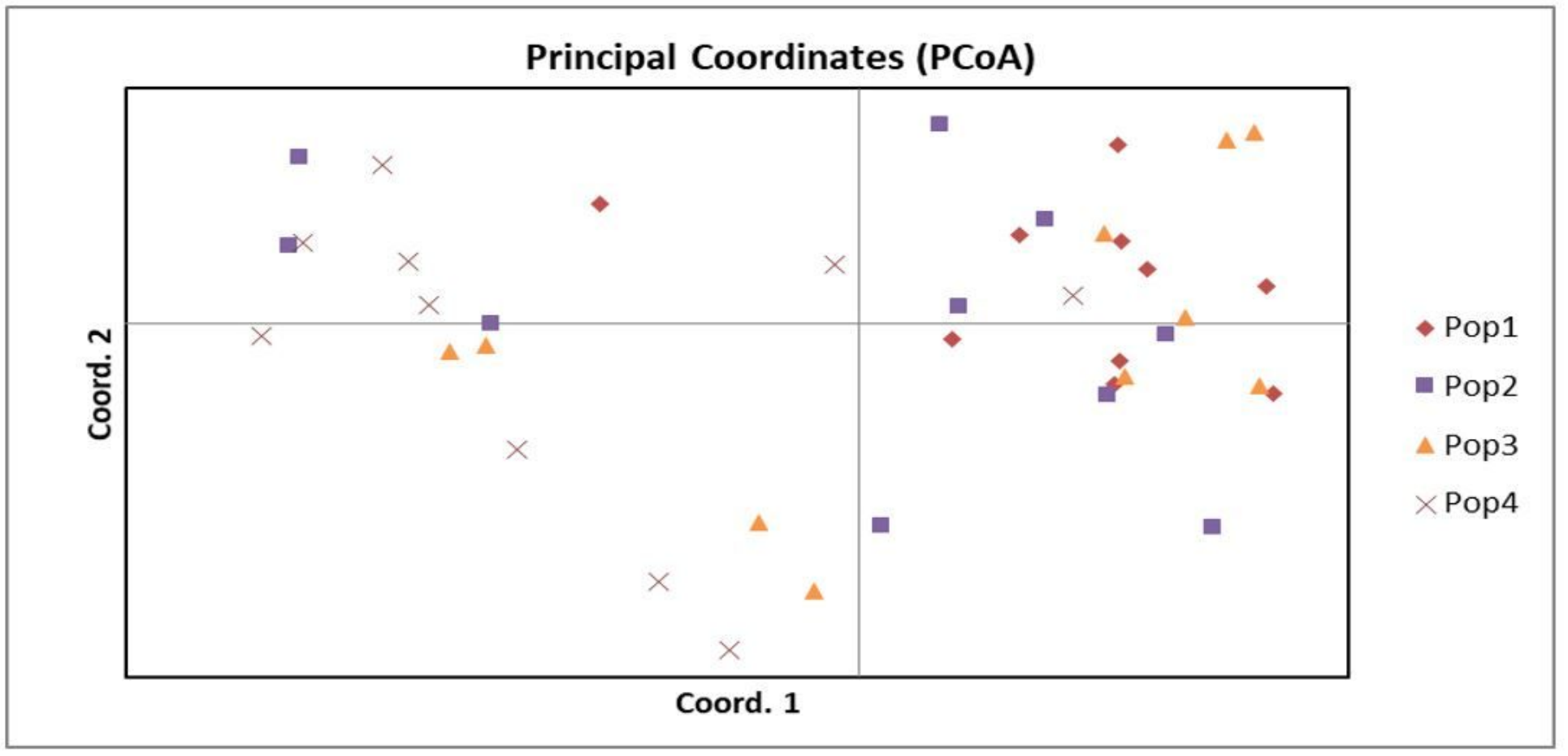

Figure 10

PCA chart for 4 populations based on genetic distances

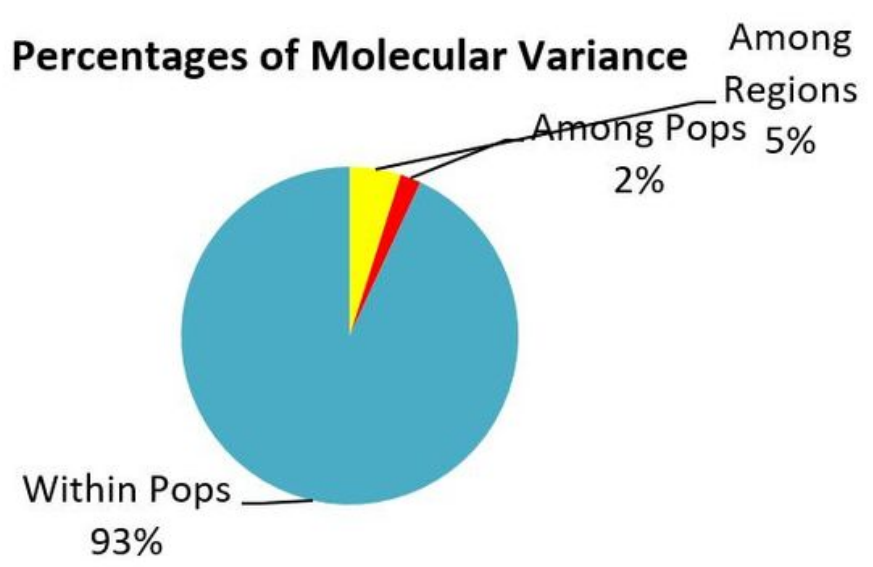

Figure 11

Molecular analysis of variance (AMOVA) between and within the population of Parasesarma persicum crab specimens. 